\title{
Writing Arts
}

\section{I feel curious, as I study abroad.}

I have seen the beauty of knowledge in university

I have experienced the new lifestyle

The new age is now, everything makes me crazy and wild.

Will you join me?

I feel alone, as I study abroad.

I left my family thousands of miles away

I left my friend, only a few still connect with me

They are my sun, make me strong and wake me up

Will you be my friend?

I feel I am diving in a sea, beautiful but silent.

I feel the gods are testing me, so I face the challenge like a warrior.

It is not enough, I must keep going.

I won't stop until I find my haven.

Haojun Yuan

\section{Daily Meaningful Sentences:}

- Tomorrow is Halloween, I have been excogitating my costume for weeks and am still vacillating.

- Today is such a gargantuan day, there are so many things that could happen or go wrong, it is making me perturbed.

- It is Friday and the week has finally culminated, I think I will luxuriate with a long shower.

- Our Halloween party is today and I am feeling very timorous, as there seems to be a lot of precipitation in the air.

- The party was a success, it gave me a feeling of exuberance, even though at times it became very boisterous.

Blake Wilson 


\title{
Carolyn Wren: Task at Hand (24 May - 20 October 2019; Curator Marcie Bronson) / Rodman Hall Art Centre, Brock University / St. Catharines, ON
}

1. I remember how the windows depict a glimpse into the outer world

2. I noticed how many of Carolyn Wren's projects involve repetition

3. The maps that are used as artwork are more about other factors including, culture, history and other factors than the use of the maps itself

4. Wren's art gives knowledge to the viewer thanks to the details of her work, such as the war map dresses.

5. Wren uses patterns in most of her artwork

Philip Van Riesen

\author{
A lipogram on " $A$ " -- \\ How come everywhere is so bright? \\ The moon is ever so white \\ Everyone is feeling just right \\ I'm just here to write \\ Until it is night. \\ Michelle Unagha
}

The commotion of the waves and the city scape. I tried. Clashing movement and the tire marks. The bird that carries the city on its back. Beauty we don't stop to appreciate, petals. The Sydney Opera House is where they sang songs about doing the best they can. The gills that breathe life. That crash wasn't supposed to happen... When it all collides, it creates chaos and the truth is in the details; you just have to open your eyes and accept it.

Ariana Thompson

\section{Six-word memoirs:}

croquet swimming seagull bathroom tiny bones lemon poppyseed board games window fog may pole dried beans fabric pennants trotting hills juice boxes white pony 
hot chocolate ice skates sparkling snow berries driftwood bonfire attic whistling lentils easter eggs bright kitchen sweet breakfast cheese bread costume changes 12:59 lullaby hide-and-seek peach dumplings swing holding hands endless garlic lunch laughter zucchini flowers radio mist smooth pebbles ocean whales playlist roof box endless travel family rock in pot exhausted cheese noodles late night music cheerios couches rumours kitchen island popcorn dogs early mornings icy sidewalks music ice cream smiles last ride quiet trusting unaware gone soft couches mismatched plates late-night laughter early morning bumpy road bike rides late night barefoot walks summer air frozen buckets road adventures questionable driving orange peels blurry photos questioning future water jugs smashing ice crunch slide calendars salad chocolate cookies late nights audience everyone awards last things scene shelves whiteboard jenga crying comfy chair drama room couch afternoon nap interrupted cinnamon buns cues headsets keys dancing stargazing secrets gentle waves under dock echo rock northern singing hugs nora tarot cards glitter lipstick mosquito graveyard six weeks smiles tight hugs unexpected balcony confessions light in a rainstorm collages lights messy floor midnight emergency hammock crackers and cheese beach walks

Sadie Snell

\section{Twictions:}

- Carl ran as fast as he could. He stumbled over his half-tied shoes, thrown on as he had fled the building. There was no time to stop and fix this. There was only time to run.

- With only thirty cents in his pocket, Kyle wondered if he would even be able to eat today. He reluctantly placed his filthy hat on the ground and began asking for change. 
- Laura had never experienced weather like this before. The wind threw her hair from side to side, as the rain flew at her like bullets, almost completely horizontally.

O Jerry thought one sandwich would be enough; "oh, just the one will hold me over till dinner," he had said; but now he realised, as his stomach grumbled loudly, it wasn't.

- The snow piled higher and higher. By this point the entire door was almost covered. Steve could only see white as he looked out the window. School definitely wasn't on.

Joel Ryder

\section{Lipogram on $\mathrm{E}$}

Th lov that a mothr has for thir child is unxplainabl

Vrything thy do, is for th child's bst intrst

At all tims, it is thir child thy think about

Nothing can stop a mothr whn sh is fighting for hr child

Nothing will vr compar to a mothr's lov

Aviguil Sam Ramos

\section{Life With No Words}

Right now, as I'm sitting down trying to think of what to write, I can honestly say that the thoughts of a world without writing has crossed my mind a few times. No more homework papers to try and cram last second, no more notes on the projector for way too many hours for a Monday night, no more "we need to talk" text messages that send your heart into your throat even though it ended up not being a big deal whatsoever. Everything could just be replaced with visuals, we could change road signs to a picture of the town that turnoff leads too, or just have a person stand above the highway and yell at cars where to go (it's an idea, I didn't say a good one). There are a lot of instances in life like this already, just looking around me now, I know exactly where the exits are in case a fire somehow breaks out. Not because there is a big red sign that says exit, but because there is a green sign showing a man going out a door, something I can understand no matter the language. I know that there is wifi because of the picture of the four bars on the paper atop of the table in front of me. I even know what time it is on my watch without any numbers on the face. It's easy to think that the world would stop spinning if words magically vanished, but think back to the Egyptians, or the Aztecs, or countless other civilizations prior to 3200BC. They used hieroglyphics and other form of pictures to tell stories and communicate. Sure you could argue that it's a form of writing, but this is my journal so I can say what I want, but the more I try to argue the side that we'd be fine, 
it's hard not to think about how much I would miss it. Sure, there would be a lot of technical issues, like the aforementioned road signs, and passing laws using drawings would make things pretty interesting, but there would also be a lot of small aspects of life changed for the worse. There would be no more funny tweets to send to your friends, no more goodnight text messages from that one person you really wanted to get a goodnight text from, there would be no more emails that you never open but never remember to unsubscribe to, and there would be no more silly journal entries for me to laugh at myself while writing. Writing is a part of every single person's daily life, so much so that we hardly ever stop to think about what life would be like if it just disappeared. It's like thinking about what would happen if corn disappeared, or wheat, or any other small thing we use every day. Things would be fine for the first few days, but surely we would see the collapse of life as we know it. Gosh, after writing this, I really hope writing stays around forever, it's exhausting being this funny with writing, I can only imagine how hard it must be to do it in person.

\section{Owen Petten}

\section{Expanding Text / 3 observations (music)}

The first observation I noticed was when the trumpet started playing first and it was a loud type of rhythm, then the saxophone joined it and became a background player, but this time it was a soft sound coming from the saxophone player.

The second observation I noticed was when all instruments began to play at the same time, the same rhythm and the same sound. They were all going on the same count and the same beat, no one off key, all in the same flow.

The third observation I noticed was, they all got their turn to have their own solo. The first person that played their solo would start off really fast and loud then slowly stop, then the next person picked up the tempo and continued; finally they all combined and started playing. After a couple of times, they started all over and again and did solos and, together, the end; everyone joined in but this time is was faster than they had ever played.

Precious Nwogu

After reading river woman by Katherena Vermette It is hard to understand something in the night. I wonder how one can study during night hours when the brain is about to shut down and the body is tired and the stress of the day has been hard.

Nighttime is for dreams, not to grasp information or learn a new language. 
It is hard to remember your dreams, try to grasp or find meaning from a dream, being able to read and understand in the night.

Blessing Nwogu

\section{Lipogram: (Vowel outlawed: $u$ )}

It was a lovely morning, Eli decided to go to the coffee shop with his friends. On the way to the destination, he met an owl. That owl had a grey coat, and her eye color was the same as the clear sky that morning. Her right eye kept closing, he wondered why. As Eli to[]ched that owl, she flew away.

Annie Nguyen

\section{Daily phrases:}

Nudiustertian I was reading my textbooks and I wondered what is all of this gobblygook?

I was not very serendipity to find that my printer was out of paper so I put in a quire.

As I xertz my milk in the morning before class I see dishes in the sink with tittynopes on them. I had a scrumptious jentacular this morning.

I wish I had more time to lollygag but my kakorrhaphiophobic stops me from doing so.

Mackenna Miranda

\section{Six Word Memoirs}

1. Summer music camp every childhood summer.

2. 14, walking through the city together.

3. Winter day at the art gallery.

4. First summer day seeing my band.

5. University fair was overwhelming but fun.

6. High school graduation was very relieving.

7. Saying goodbye to all the toxicity.

Arielle Hounsham-Lalande 
Colourful, trees, waving in the wind, one motion, forest environment, different colour leaves on the ground, light green, springtime, ground water, mirror, tall trees, walking trail, exuberant, black, pink, purple, red, pine trees, colours blended, ravine, rainforest, stream effect, flowers, trees blooming, pastel, camp atmosphere, Auntie Sue's backyard, wildlife, landscape, Deer, rabbits, fairy-tale forest.

Sarah Fischer

\section{5 twictions}

A fallen leaf, red and gold. Alone on the wind, drifting down. In the chilly breeze, do you ever get cold? Land by me, \& I can't even frown.

Glowing petals, gold and magical. Murmur a blessing, send me home. Skeletons smile as they dance and sway. Sing to me, before I drift away.

En mi corazón es donde vives. Llorona, te ves hermosa en azul celeste, tus lágrimas caen sobre tu vestido. Mi llorona, no dejaré de quererte

"When pigs fly!" they scoff and laugh. Meanwhile, in the barn...

A young pig, in the pigsty, puts his little wings on, and takes to the sky.

The corn field is where they stay. Tupac and Bob Ross, hiding away. They chomp and chomp, cob after cob. Crows eat too but got nothing on Bob.

Sydni Ebanks

\section{Roses and red}

Violets are blue

My heart is made out of goo

Blue is for mothers

Grey is for lovers

And blank canvases are for me and you

Strokes of gray black and blue

Landscapes of unfinished lines

Emergent they stand like crystal skyscrapers

The ocean moans and gapes

Forgotten words and insincere thoughts

Pale in comparison to feeling distraught 
Help me

I can't swim

I feel like drowning on a whim

Blank thoughts and blank canvases become consumed

By vibrant colours and racing thoughts

Goodbye.

Elizabeth Cuviello

\section{Lipogram: no "o"}

The car is packed, luggage stacked, and engine running. The entire family piles in, readying themselves in the name of a lengthy trip. Dad is driving, Ma is mapping, the kids entertaining themselves with games and puzzles. They hit the street, pulling away from the pad with the aquatic vessel behind them. They make it as far as the highway, perusing the en-ramp, when dad realizes, "I left the lifejackets at the residency." They turn back, as it is illegal to captain a ship lacking the life vests.

Elizabeth Anderson

(Ed. Catherine Parayre) 